\title{
PENGISIAN AKI DENGAN BUCK CONVERTER
}

\author{
Oleh : \\ Yul Antonisfia, Era Madona \\ Staf Pengajar Jurusan Teknik Elektro Politeknik Negeri Padang \\ Email :yul_antoni@yahoo.com,emadona38@gmail.com
}

\begin{abstract}
Buck converter is one of DC chopper which has the function of stabilizing the voltage to lower voltage where the output voltage is lower than the input voltage without having to remove power is relatively large. By using a buck converter is a high voltage can be reduced to lower as you wish without losing power is relatively large. The voltage output of the buck converter is able to charge the battery. The magnitude of the output voltage depends dutycyle switching generated by the microcontroller. This tool is also equipped with a flow sensor is used to detect the charging current into the battery. If the charging current is reduced, the buzzer will sound. The tool is based microcontrollers using BASCOM ATMEGA8535, which can generate a PWM with dutycyle specified. Dutycyle determined the size of the input voltage and the desired output.
\end{abstract}

Keywords : microcontroller, buck converter,sensor arus

\section{PENDAHULUAN}

Alat pengisian aki biasanya memakai trafo dan dioda bridge saja. Arus pengisiannya tidak stabil yang dapat merusak aki. Oleh karena itu maka penulis membuat sebuah converter $D C$ to $D C$ yang bernama buck converter yang digunakan untuk mengisi aki.

Buck converter merupakan salah satu jenis $D C$ chopper yang memiliki fungsi menstabilkang tegangan dengan menurunkan tegangan dimana tegangan keluaran lebih rendah dari tegangan masukan tanpa harus menghilangkan daya yang relatif besar. Sistem pengendaliannya menggunakan mikrokontoller merupakan alternatif sistem kendali modern yang mudah karena tidak perlu dicari model matematis dari suatu sistem, tetapi tetap efektif karena memiliki respon sistem yang stabil. Dalam tugas akhir ini penulis mengatur dutycycle tetap, dengan tegangan input dari power supply sebesar
$21 \mathrm{~V}$ dan tegangan output untuk pengisian ke aki sebesar $13 \mathrm{~V}$ dan arus pengisian $1 \mathrm{~A}$. Pada alat ini penulis menambahkan detektor aki penuh. Jika aki telah penuh buzzer akan berbunyi. Untuk dapat mengontrol tegangan masukan sebesar $21 \mathrm{~V}$ menjadi $13 \mathrm{~V}$ yang digunakan untuk mengisi aki, keseluruhan arsitektur sistem dapat digambarkan seperti gambar berikut

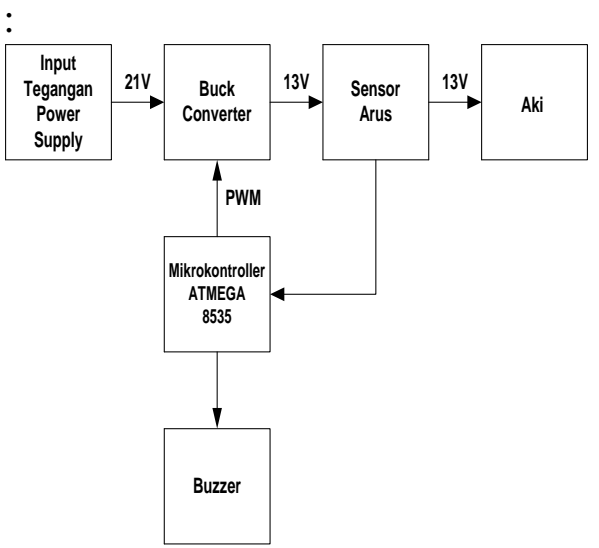

Gambar 1. Blok diagram sistem 
Pada blok diagram diatas adalah sebuah sistem yang dapat mengisi aki dengan tegangan dan arus maksimal pengisian sebesar 13V/1A. Disini tegangan dan arus input yang diberikan dari power supply sebesar 21V/5A. Sedangkan tegangan dan arus output yang dibutuhkan untuk pengisian sebesar 13V/1A. Jadi untuk dapat menurunkan tegangan dari $21 \mathrm{~V}$ menjadi $13 \mathrm{~V}$ maka dirancanglah sebuah Buck Converter. Mikrokontroller ini berfungsi sebagai pemberi pulsa pulsa (PWM) ke buck converter yang nilai duttycyle nya diatur tetap. Besarnya duttycyle ini akan berpengaruh terhadap besarnya tegangan output. Sedangkan sensor arus berfungsi sebagai mendeteksi besarnya arus pengisian ke aki. Sehingga apabila aki telah terisi penuh maka besarnya arus pengisian akan berkurang dan buzzer akan berbunyi (memberi peringatan).

\section{TUJUAN}

> Menerapkan buck converter sebagai pengisian aki

$>$ Membuat alat penstabil dan penurun tegangan (step down) untuk mengisi Aki yang dilengkapi dengan detektor aki penuh

\section{RUMUSAN MASALAH}

Bagaimana menghasilkan tegangan keluaran yang konstan untuk pengisian aki

$>$ Bagaimana merancang bangun sebuah buck converter dengan tegangan input sebesar $21 \mathrm{~V}$ sehingga tegangan ouputnya menjadi $13 \mathrm{~V}$ dengan kendali PWM nya adalah mikrokontroller AVR ATMEGA 8535

\section{BATASAN MASALAH}

> Sistem ini dirancang dengan kendali PWM yang dihasilkan oleh mikrokontroller ATMEGA 8535.

$>$ Nilai duttycyle nya tetap sesuai dengan tegangan output yang dibutuhkan untuk pengisian aki

\section{METODOLOGI}

Metode yang digunakan dalam penyelesaian tugas akhir ini adalah melakukan studi literatur, menentukan nilai dutycyle switching, pembuatan sistem dan pengujian sistem. Rinciannya adalah sebagai berikut :

\section{Studi literatur}

Mengumpulkan informasi dan referensi yang berkaitan dengan topik penelitian.

2. Menentukan nilai dutycyle switching Besarnya tegangan output akan ditentukan oleh duttycyle pwm yang dihasilkan oleh mikrokontroller. Untuk mendapatkan tegangan ouput $13 \mathrm{~V}$ dari input $21 \mathrm{~V}$ maka harus ditentukan duttycyle sebagai berikut :

Diketahui : $\mathrm{V}_{\text {in }}=21 \mathrm{~V}$

$$
\mathrm{V}_{\text {out }}=13 \mathrm{~V}
$$

Ditanya : duttycyle ?

Jawab : dutycyle $=\mathrm{V}_{\text {out }} / \mathrm{V}_{\text {in }}$

$$
\begin{aligned}
& =13 \mathrm{~V} / 21 \mathrm{~V} \\
& =0.6
\end{aligned}
$$

Dalam persentase adalah: $0.6 \times 100 \%$ $=60 \%$

\section{Pembuatan sistem}

a. Rangkaian power supply

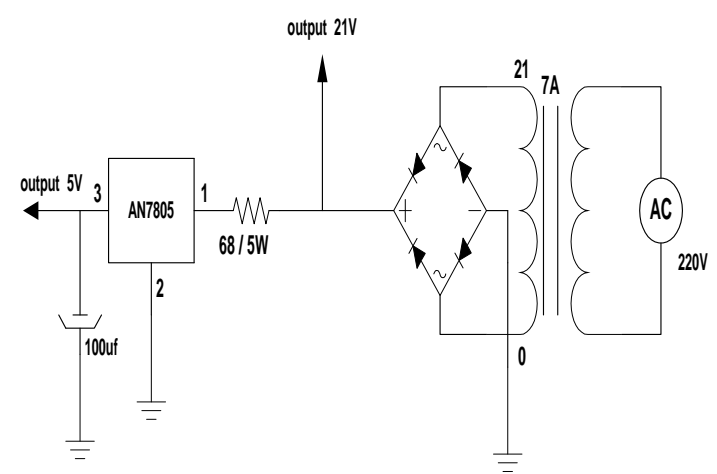

Gambar 2. Power Supply

rangkaian diatas digunakan sebagai sumber tegangan. Trafo digunakan sebagai 
penurun tegangan AC. Sedangkan diode bridge digunakan sebagai penyearah tegangan dari trafo tersebut. Selanjutnya IC AN7805 digunakan sebagai regulator yang menghasilkan tegangan $5 \mathrm{~V}$ DC. Tegangan 5V DC ini digunakan sabagai supply untuk sistem minimum ATMEGA 8535

b. Rangkaian Buck Converter

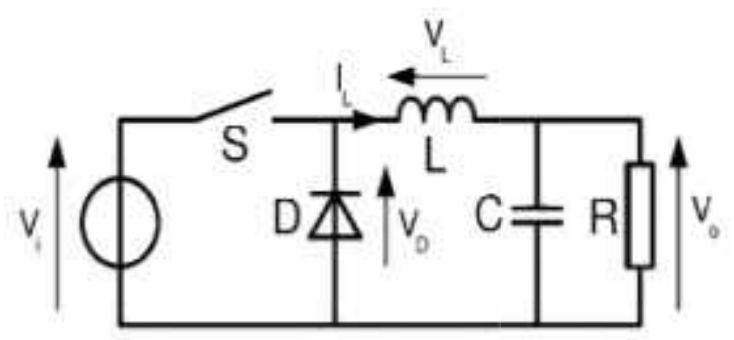

\section{Gambar 3. Buck Converter}

Buck Converter menghasilkan tegangan output yang lebih kecil dari tegangan masukan. Cara kejanya adalah :

1. Ketika switch closed : dioda bekerja reversed/block sehingga suplai input mengalir ke induktor juga ke beban.

2. Ketika switch opened : dioda bekerja forward/unblock sehingga energi yang disimpan di induktor dapat mengalir ke beban.

c. Rangkaian sistem minimum

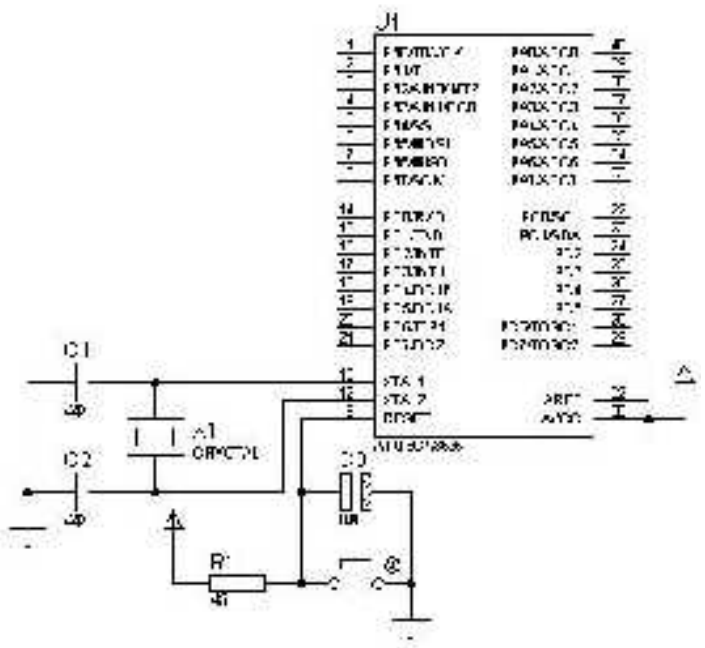

Gambar 4. Sistem Minimum ATMEGA 8535 kegunaan masing masing PORT yang dipakai pada mikrokontroller:

\begin{tabular}{|c|c|}
\hline PORT & Kegunaan PORT \\
\hline PORTD.5 & Sebagai output PWM \\
PORTB.0 & Sebagai output ke Buzzer \\
PORTA.0 & Sebagai Input masukan dari sensor arus \\
\hline
\end{tabular}

d. Rangkaian sensor arus

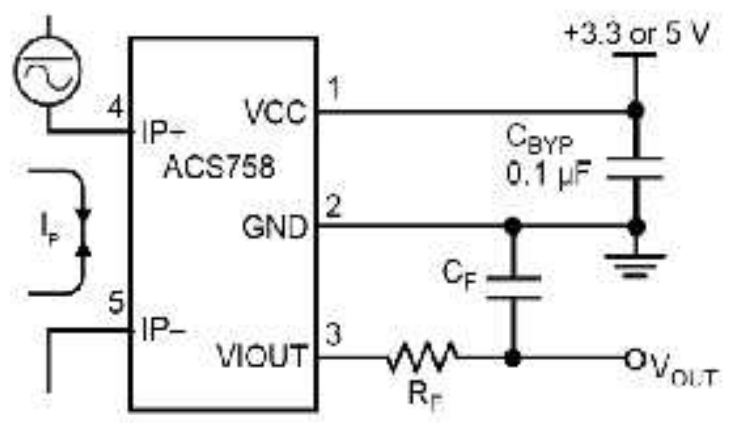

Gambar 5. Sensor Arus

Sensor ini memiliki pembacaan dengan ketepatan yang tinggi, karena didalamnya terdapat rangkaian low-offset linear Hall dengan satu lintasan yang terbuat dari tembaga. cara kerja sensor ini adalah arus yang dibaca mengalir melalui kabel tembaga yang terdapat didalamnya yang menghasilkan medan magnet yang di tangkap oleh integrated Hall IC dan diubah menjadi tegangan proporsional.

e. Program

Untuk membuat program control alat ini, penulis menggunakan software BASCOM AVR. Software ini dapat digunakan untuk pembuatan program control bagi mikrokontroller keluarga AVR. Untuk memulai pemograman dengan menggunakan BASCOM AVR yaitu dengan memilih 'create a new file' pada header halaman awal tampilan. Setelah itu, maka kita bisa langsung 
membuat program. Program untuk system ini adalah sebagai berikut:

Program header :

$$
\begin{aligned}
& \text { \$regfile }=" \text { m8535.dat" } \\
& \text { \$crystal }=11059200
\end{aligned}
$$

Ini dimaksudkan untuk mengisikan bahwa kita menggunakan controller AVR ATMEGA 8535. Dan Kristal yg kita gunakan adalah Kristal eksternal sebesar 11.059.200Hz.

Program utama PWM :

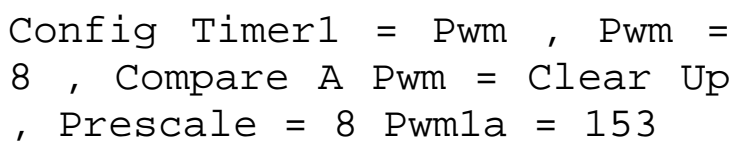

Dalam sistem ini hanya menggunakan 1 buah PWM yang mana outputnya dikeluarkan pada PORTD.5. untuk mendapatkan tegangan output sebesar $13 \mathrm{~V}$ maka harus mengatur duttycyle switching dengan tepat agar keluaran yang didapatkan sesuai dengan keinginan. Dalam program diatas penulis menggunakan timer 1 dan menggunakan pwm 8bit dengan mode non inverting. Untuk mengatur nilai duttycyle nya maka penulis mengatur di PWM1a. Untuk merubah tegangan dari power supply sebesar $21 \mathrm{~V}$ menjadi $13 \mathrm{~V}$ pada perhitungan duttycyle dibutuhkan duttycyle sebesar 60\%. Oleh karena itu pada pembuatan program ini maka :

Untuk duttycyle $0-100 \%$ berkisar dari $0-$ 255 (karena menggunakan PWM 8bit). Jadi untuk duttycyle 1\% maka Pwm1a = $255 / 100=2.55$

Sehingga untuk duttycyle $60 \%$ maka Pwm1a nya $=60 * 2.55=153$

Program utama untuk aki penuh

Config Portb.0 = Output

Config Porta.0 = Input

Config Adc $=$ Single,

Prescaler $=$ Auto

Start Adc

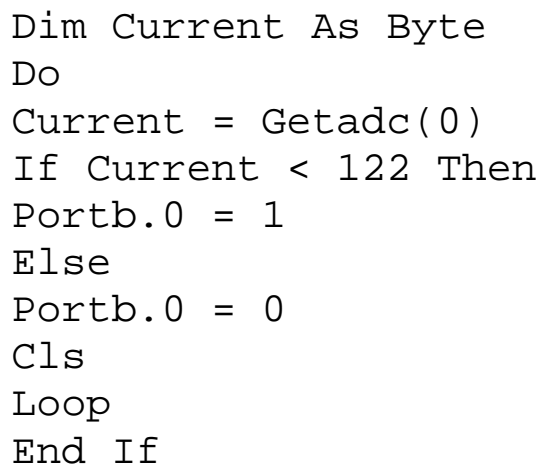

Dari program diatas penulis memakai ADC 8bit yang berkisar dari 0 255 desimal dengan tegangan input dari sensor yaitu $0-5 \mathrm{~V}$. Dari pengukuran tegangan output sensor secara manual didapat ketika aki penuh sebesar $=2.3 \mathrm{~V}$. berarti tegangan output dari sensor ketika aki penuh adalah kecil dari $2.4 \mathrm{~V}$, sedangkan $\mathrm{V}_{\text {ref }}$ diberikan pada sebesar $5 \mathrm{~V}$. Untuk tegangan $2.4 \mathrm{~V}$ maka ADC nya adalah :

$$
\text { Rumus : } \begin{aligned}
\mathrm{ADC} & =\mathrm{V}_{\text {in }} * 255 / \mathrm{V}_{\text {ref }} \\
& =2.4 \mathrm{~V} * 255 / 5 \mathrm{~V} \\
& =122
\end{aligned}
$$

Cara kerja program diatas yaitu pertama semua port dikonfigurasikan dulu. Setelah itu data dari PORTA.0 akan dimasukkan ke variable "current", setelah itu data tersebut dicek apakah sudah kecil dari 122 desimal? kalau sudah portb.0 akan bernilai high dan buzzer berbunyi karena buzzer aktif high. selain dari pernyataan diatas portb.0 akan bernilai low (buzzer mati) dan kembali looping ke atas. 


\section{Pengujian sistem}

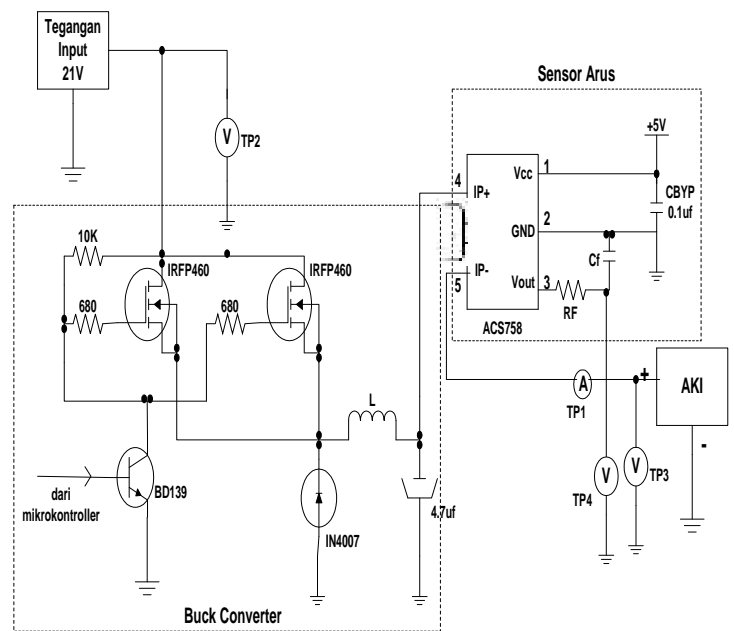

Gambar 6 Titik Pengukuran

Tabel 1 hasil pengukuran saat pengisian ke aki 7A

\begin{tabular}{|c|c|c|c|c|c|}
\hline $\begin{array}{c}\text { Waktu } \\
\text { pengisian }\end{array}$ & TP1 & TP2 & TP3 & TP4 & Status Buzzer \\
\hline 1menit & $1.1 \mathrm{~A}$ & $21 \mathrm{~V}$ & $11.8 \mathrm{~V}$ & $3.1 \mathrm{~V}$ & off \\
$2 \mathrm{menit}$ & $798 \mathrm{~mA}$ & $21 \mathrm{~V}$ & $12.8 \mathrm{~V}$ & $2.84 \mathrm{~V}$ & off \\
4menit & $621 \mathrm{~mA}$ & $21 \mathrm{~V}$ & $13 \mathrm{~V}$ & $2.78 \mathrm{~V}$ & off \\
8 menit & $330 \mathrm{~mA}$ & $21 \mathrm{~V}$ & $13 \mathrm{~V}$ & $2.65 \mathrm{~V}$ & off \\
15 menit & $175 \mathrm{~mA}$ & $21 \mathrm{~V}$ & $13 \mathrm{~V}$ & $2.51 \mathrm{~V}$ & off \\
30 menit & $150 \mathrm{~mA}$ & $21 \mathrm{~V}$ & $13 \mathrm{~V}$ & $2.45 \mathrm{~V}$ & off \\
60 menit & $140 \mathrm{~mA}$ & $21 \mathrm{~V}$ & $13.5 \mathrm{~V}$ & $2.42 \mathrm{~V}$ & off \\
180 menit & $75 \mathrm{~mA}$ & $21 \mathrm{~V}$ & $13.5 \mathrm{~V}$ & $2.37 \mathrm{~V}$ & on \\
\hline
\end{tabular}

Tabel 2 hasil pengukuran saat pengisian ke aki 10A

\begin{tabular}{|c|c|c|c|c|c|}
\hline $\begin{array}{c}\text { Waktu } \\
\text { pengisian }\end{array}$ & TP1 & TP2 & TP3 & TP4 & Status Buzzer \\
\hline Imenit & $1.2 \mathrm{~A}$ & $21 \mathrm{~V}$ & $11.9 \mathrm{~V}$ & $3.2 \mathrm{~V}$ & off \\
2menit & $868 \mathrm{~mA}$ & $21 \mathrm{~V}$ & $12.5 \mathrm{~V}$ & $2.88 \mathrm{~V}$ & off \\
4menit & $650 \mathrm{~mA}$ & $21 \mathrm{~V}$ & $12.8 \mathrm{~V}$ & $2.78 \mathrm{~V}$ & off \\
8 menit & $350 \mathrm{~mA}$ & $21 \mathrm{~V}$ & $13 \mathrm{~V}$ & $2.67 \mathrm{~V}$ & off \\
$15 \mathrm{menit}$ & $180 \mathrm{~mA}$ & $21 \mathrm{~V}$ & $13 \mathrm{~V}$ & $2.55 \mathrm{~V}$ & off \\
$30 \mathrm{menit}$ & $160 \mathrm{~mA}$ & $21 \mathrm{~V}$ & $13 \mathrm{~V}$ & $2.48 \mathrm{~V}$ & off \\
60menit & $145 \mathrm{~mA}$ & $21 \mathrm{~V}$ & $13.5 \mathrm{~V}$ & $2.45 \mathrm{~V}$ & off \\
195menit & $76 \mathrm{~mA}$ & $21 \mathrm{~V}$ & $13.5 \mathrm{~V}$ & $2.38 \mathrm{~V}$ & on \\
\hline
\end{tabular}

Dari tabel pengujian, didapat hasil pengukuran arus pengisian ke aki yang besarnya akan berkurang jika waktu pengisian semakin lama. Buzzer berbunyi jika arus pengisian berkurang yang mengakibatkan tegangan output pada sensor (TP4) kurang dari $2.4 \mathrm{~V}$. perbedaan tabel 1 dan 2 adalah terletak pada lamanya pengisian sampai buzzer berbunyi.

\section{Kesimpulan}

$>$ Buck Converter dapat diterapkan sebagai alat pengisian aki dengan tegangan konstan yang dilengkapi dengan detektor aki penuh

$>$ Ketika aki kosong arus pengisian mencapai 1.2A dan tegangan pada aki $11.8 \mathrm{~V}$

$>$ Aki penuh dan buzzer berbunyi jika arus pengisian mencapai $76 \mathrm{~mA}$, tegangan pada aki $13.5 \mathrm{~V}$ dan tegangan output pada sensor kurang dari $2.4 \mathrm{~V}$

$>$ Besarnya tegangan output yang dihasilkan bergantung dari dutycyle nya

$>$ Tegangan input $21 \mathrm{~V}$ diturunkan menjadi 13 Vdengan dutycyle $60 \%$

$>$ Apabila aki semakin besar maka waktu pengisiannya semakin lama

$>$ Berkurangnya arus pengisian Saran bergantung dari waktu pengisian

Arus input yang diberikan sebaiknya lebih dari 5 Ampere

Pemakaian alat ini lebih efisien jika input tegangan diberikan dari solar cell dari pada dari power supply

\section{DAFTAR PUSTAKA}

Wisnu.Adi. 1972. mikrokontroller ATMEGA 8535. UGM:Yogyakarta

Malvino. Albert Paul. 2003. prinsipprinsip Elektronika, buku satu, penerbit Salemba Teknika: Jakarta

Winoto.Ardi. 2010. Mikrokontroller AVR ATMEGA8/32/16/8535 dan pemogramannya, edisi revisi, informatika: Bandung

Rusmadi. Dedy. 1987. Pengenalan dasar elektronika, jilid 1,2,3. Sinar baru Del Fajar Utama : Bandung 
ISSN :2085-6989

HALAMAN INI SENGAJA DIKOSONGKAN 